\title{
Some Research Opportunities in the Papers of Edwin T. Meredith, 1876-1928
}

Shortly before his death in June 1966, Edwin T. Meredith, Jr. presented a large collection of his father's correspondence to The University of Iowa Libraries. Although the original gift represented the bulk of the elder Meredith's surviving papers, subsequent additions by members of the family and the Meredith Publishing Company have increased the total amount of material to well over 26,000 items. $^{1}$ These papers have been processed and are now open for research in the Special Collections Department of The University of Iowa Libraries.

Edwin Thomas Meredith was born at Avoca, Iowa, on December 23, 1876, the eldest of the seven children of Thomas Oliver and Minerva J. (Marsh) Meredith. His father was a farm implement dealer at Avoca for several years before moving to nearby Marne, where he farmed. In 1892 "Ed" was sent to Des Moines to live with his grandfather while attending what was then Highland Park College. ${ }^{2}$ Thomas Meredith, Edwin's grandfather, had prospered in the buying and selling of land in western Iowa. After his retirement, "Uncle

${ }^{1}$ Anyone consulting the Meredith Collection should ask for the index, a valuable finding aid prepared by the staff of the Special Collections Department of the Library. Generally, only correspondence was given item numbers. In addition, the collection contains four bound volumes of Meredith's speeches, sixteen scrapbooks of neatly ordered newspaper clippings, two albums of photographs, and several file boxes of nonitemized material.

2 History of Pottawattamie County Iowa (Chicago, 1883), p. 138; Lafe Young, History of Cass County lowa with Brief Mention of Old Settlers (Atlantic, Iowa, 1877), pp. 57-58; Edwin T. Meredith to Alson Secor, n.d., Meredith papers. All correspondence cited hereafter is in the Meredith papers unless otherwise indicated. 
Tommy" moved to Des Moines, where, by 1892 , he had become the chief financial sponsor of a weekly reform newspaper. Edited by General James B. Weaver, the Farmers' Tribune was the major organ of the People's or "Populist" Party in Iowa. And it was in the offices of this small paper that Edwin T. Meredith began his great publishing career. ${ }^{3}$

In the spring of 1894 the younger Meredith became the general manager of his grandfather's paper. It was a very exciting position for a youth of eighteen and, as he later remembered, he had then viewed the Farmers' Tribune as "about the biggest thing on earth." But the People's Party was on the wane. General Weaver resigned to make an unsuccessful bid for Congress. The paper continued to lose money, and Uncle Tommy had virtually decided to let it fold. His young general manager protested; so in 1896 Thomas Meredith sold half interest in the Farmers' Tribune to S. B. Crane and gave his newly married grandson the other half as a wedding gift. ${ }^{5}$

Young Meredith quickly bought out Crane and gradually transformed the Farmers' Tribune into a statewide farm paper. He increased the circulation to about 30,000 and, in his words, "made a small profit" each year. ${ }^{6} \mathrm{He}$ had far bigger things in mind, however, when he began publication of a new monthly magazine designed expressly for the farmers of the agriculturally rich Midwest. The first issue of Successful Farming, appearing in October 1902, contained only 16 pages and little advertising. From the beginning no liquor or tobacco advertisements were accepted. Nonpartisan and devoted to the "discussion of farm matters employed in making farming a success," " the publication soon attracted both advertisers and subscribers. By 1908 well over 100,000 farm families were subscribers to Successful Farming. With the rapid growth of Successful Farming came nationwide recognition for its publisher.

Meredith served as President of both the Agricultural Publishers Association and the Associated Advertising Clubs of the World. With the establishment of the federal reserve system, he was named a

3 Frank Luther Mott, "Iowa Magazines," Palimpsest, XLIV (August 1963), 351-352; Theodore Bernard Peterson, Magazines in the Twentieth Century (2nd ed. Urbana, 1964), p. 383.

4 Meredith to Secor, n.d.

5 Mott, "Iowa Magazines," 352; Farmers' Tribune, January 8, 1896.

6 Meredith to R. W. Dennis, May 3, 1926.

' Successful Farming, I (October 1902), 2. Meredith sold the Farmers' Tribune in 1904. 
director of the Chicago Federal Reserve Bank. In 1915 he was elected to the Board of Directors of the Chamber of Commerce of the United States. Throughout this period he was instrumental in promoting the growth of the National Committee on Boys' and Girls' Club Work, one of the forerunners of the 4-H Clubs. ${ }^{8}$ But, increasingly, politics was the activity that attracted Meredith's interest.

He had been active in political affairs before he was of voting age. At eighteen he was the Secretary of the State Central Committee of the People's Party. Later, after the decline of Populism, he voted Republican. Attracted to the 1912 campaign of Woodrow Wilson, Meredith became one of the President's most ardent supporters in Iowa, and after 1912 his loyalty lay with the Democratic Party.

At the urging of friends, Meredith entered the 1914 contest for the Democratic senatorial nomination. His opponent, Congressman Maurice Connelly, using Meredith's previous Republicanism as an effective issue, won the nomination, only to be defeated by the Republican incumbent, Albert B. Cummins. Meredith was gracious in defeat. His work for the 1914 ticket won the respect of many Iowa Democrats. Two years later, at a Party caucus, he was asked to be the Democratic candidate for Governor. His accepted only after assurances from Party leaders that he could run on a platform containing two major planks, prohibition and good roads. ${ }^{9}$

The Republican candidate, Lieutenant Governor William Lloyd Harding, was generally viewed as a "wet," and he had the support of the "mud road insurgents" who vociferously opposed most so-called good road proposals. Throughout much of the bitter campaign, the politically adroit Harding kept Meredith on the defensive. In November, the Des Moines publisher received less than 28 per cent of the votes cast. ${ }^{10}$ The 1916 race for governor marked the last time that he would actively seek elective political office.

Despite his defeat, Meredith's service on behalf of agriculture and the Democratic Party did not go unnoticed during Wilson's second term. The President appointed him to the American Labor Mission

${ }^{8}$ Edwin T. Meredith 1876-1928: A Memorial Volume (Des Moines, 1931), pp. 17-18; "Edwin T. Meredith," Annals of lowa, XXIX (April 1949), $569 f$.

9 Des Moines Register, April 16, 1916.

10 John Thomas Schou, "The Decline of the Democratic Party in Iowa, 1916-1920" (Unpublished M.A. Thesis, University of Iowa, 1960), p. 172; John E. Visser, "William Lloyd Harding and the Republican Party in Iowa, 1906-1920" (Unpublished Ph.D. Dissertation, State University of Iowa, 1957), p. 174. 
which visited England and France in 1918, and to the Treasury Department's Advisory Committee on Excess Profits. Meredith received his greatest honor when, in the closing months of his administration, President Wilson named him Secretary of Agriculture. ${ }^{11}$

During the first few months of Meredith's brief tenure as Secretary, he concentrated on publicizing the myriad activities of the Department. After farm prices broke sharply in the fall of 1920, he broadened his efforts to stress the "fundamental importance" of agriculture to the national economy. ${ }^{12}$ Gradually he developed a plan for farm relief which he hoped would end the recurrent economic instability of American agriculture. By his own admission, the plan never attracted many supporters; yet, as he wrote Newton Baker in 1927, it remained "more or less an obsession" with him. ${ }^{13}$

With the advent of the Harding administration in 1921, once again Meredith was able to devote his energies to publishing. He first purchased another farm journal, the Dairy Farmer, subsequently to be incorporated into Successful Farming. A few months later, in October 1922, the first copies of yet another publication, Fruit, Garden and Home, rolled off the Meredith presses in Des Moines. Renamed Better Homes and Gardens in 1924, this magazine soon became, and remains, one of the nation's major publications in terms of circulation and advertising revenue. ${ }^{14}$

Even with the increased demands on his time created by the new publications, Meredith never lost touch with the political scene. In 1923 he joined a group of "dry, progressive Democrats" (as they described themselves) who were actively supporting William Gibbs McAdoo's drive for the 1924 Democratic presidential nomination. He had unsuccessfully urged the Iowa delegation to cast their ballots for McAdoo at the 1920 convention in San Francisco. ${ }^{15}$ Now, to

11 Woodrow Wilson to Meredith, January 26, 1920; Meredith to Wilson, January 26, 1920. Copies of both telegrams in the possession of Edwin $\mathrm{T}$. Meredith III.

12 Edwin T. Meredith, "Business and Agriculture," The North American Review, CCXIV (October 1921), 461-469; Gladys Baker et al., Century of Service (Washington, 1963), pp. 97-101; Meredith to Josephus Daniels, March 18, 1924, Daniels papers, Library of Congress.

13 Meredith to Newton Baker, May 24, 1927.

14 Peterson, Magazines in the Twentieth Century, pp. 382-383. N. W. Ayer \& Son's Directory for 1967 records a total net paid circulation figure of 6,882,558 copies.

15 Meredith to William Gibbs McAdoo, July 26, 1920, McAdoo papers, Library of Congress. 
assure McAdoo of Iowa's backing in 1924, Meredith, Clyde Herring, Claude Porter, and others, set out to gain control of the Party organization within the state. By a narrow margin they ousted Wilbur Marsh, Iowa's long-time national committeeman and a staunch McAdoo foe. . $^{16}$

The state's delegation, headed by Meredith, remained loyal to McAdoo throughout the wearisome 1924 Party gathering in New York's Madison Square Garden-the longest convention in the history of the Democratic Party. As the deadlocked delegates neared the 100th ballot, McAdoo released his backers with the admonition that they cast their votes for Meredith. The nomination, however, went to John W. Davis on the 103rd ballot. Davis then offered Meredith second place on the ticket, but the Des Moines publisher declined, and the nomination went to Charles Bryan of Nebraska. ${ }^{17}$

The Party debacle of 1924 dismayed Meredith. For the next three years he repeatedly warned dry, progressive Democrats that unless they settled on a candidate for 1928 , the nomination would go to Al Smith by default. "It is the same old proposition of not being able to beat someone with no one," he wrote McAdoo in August, 1927.18 Meredith found that few people shared his anxiety, and he became more and more disheartened. In September he told Josephus Daniels that he would weep on his shoulder the next time they met "because of the situation of the Democratic Party, as I view it."19

Finally, in early 1928, he reluctantly agreed that his name be presented to the state convention as a favorite son candidate in an effort to head off Al Smith. Because of illness he took little or no part in the actual campaign. While the Iowa Democratic convention was overwhelmingly endorsing Al Smith, Meredith lay seriously ill in Johns Hopkins hospital in Baltimore with complications resulting from high blood pressure. In April he entered a period of convalescence at his home in Des Moines, but after several weeks of improve-

16 Meredith to David L. Rockwell, March 29, 1924; Meredith to Cato Sells, April 7, 1924.

17 David H. Stratton, "Splattered with Oil: William G. McAdoo and the 1924 Democratic Presidential Nomination," Southwestern Social Science Quarterly, XLIV (June 1963), 74; Lee N. Allen, "The McAdoo Campaign for the Presidential Nomination in 1924," The Journal of Southern History, XXIX (May 1963), 226-227; David Burner, "The Democratic Party in the Election of 1924," MidAmerica, XLVI (April 1964), 100-102; Copy of press release prepared by Meredith for the Des Moines Register upon his return from the convention.

18 Meredith to McAdoo, August 22, 1927.

19 Meredith to Daniels, September 10, 1927. 
ment his condition suddenly worsened and he died on June 17, 1928.

Several writers have lightly chastised their fellow historians for concentrating on the New Deal and the Progressive Era while unduly neglecting the 1920 's. ${ }^{20}$ But recently, scholars have made inroads in this murky valley between the two peaks of reform. This research has uncovered about as many questions as it has answered. It has also emphasized the difficulty of locating manuscript sources. ${ }^{21}$ Herein lies the value of the Meredith collection. These papers offer ample research opportunities in at least four areas: Democratic politics on the state and national level; publishing; farm relief; and the development of arid western lands under the Carey Act.

POLITICS. Meredith took part in an exceptionally heavy and frank political correspondence with many Iowa Democrats throughout the 1920 's. ${ }^{22}$ These letters comprise what is certainly the most extensive manuscript source for Iowa Democratic politics in the 1920 's, if not for the first half of the twentieth century. Early in 1924 Meredith sent a form letter to over 900 Iowa Democrats asking for their comments on the condition of the Party in their locale, while at the same time urging their support of McAdoo. Approximately one hundred of the recipients replied to the inquiry, and their combined letters form a unique grassroots view of local politics. A close examination

20 For discussion of the historiography of the period see: John D. Hicks, "Research Opportunities in the 1920's," Historian, XXV (November 1962), 1-13; Don S. Kirschner, "Conflicts and Politics in the 1920's: Historiography and Prospect," Mid-America, XLVIII (Oc'ober 1966), 219-233; Henry F. May, "Shifting Perspectives on the 1920's," Mississippt Valley Historical Review, XLIII (December 1956), 405-427; Burt Noggle, "The Twenties: A New Historiographical Frontier," Journal of American History, LIII (September 1966), 299-314.

21 Hicks, "Resarch Opportunities in the 1920's," p. 2.

29 When he returned from Washington in 1921, Meredith acquired a new private secretary, Lester Mugge. Now the Senior Vice President of Meredith Publishing Company, Mugge carefully preserved his employer's correspondence, including carbons of outgoing letters. Thus the collection contains both incoming and outgoing letters. Clyde Herring, Claude Porter, Harry C. Evans, Eugene Feuling, Fay J. Files, Daniel Steck, and Madge O'Neil were among the many Iowa Democrats who corresponded with Meredith. There is only a small amount of material dated before 1921, and the papers add little to what has already been written about the early growth of Meredith Publishing Company and Iowa politics during the two terms of Woodrow Wilson. Just what happened to the earlier correspondence is unclear, but the abundance and richness of the post-1921 material serves to offset much of the disappointment over the scarcity of early letters. 
of this aspect of the Meredith collection in conjunction with a quantitative analysis of voting patterns might prove rewarding.

Meredith sent two additional form letters in 1924. The first one, commenting on the recent convention, went to Democrats across the nation in July. After the disastrous Party defeat in November, Meredith again wrote Democratic leaders. This time he suggested a conference aimed at restoring Party harmony. The replies to both letters merit study. Meredith and many of his correspondents viewed themselves as representatives of the progressive tradition within the Democratic Party. Their letters may therefore shed light on the continuing controversy over what happened to progressivism during the period of Republican ascendancy. ${ }^{23}$ And, as the Meredith papers are remarkably complete for the 1920 's, they will serve as an important supplement for other collections. ${ }^{24}$

PUBLISHING. During this same decade of the ' 20 's mass advertising was a prime stimulant in the growth of consumer spending and this spending, in turn, was a comerstone of what has been called America's "second industrial revolution." 25 As past President, Meredith was active in the affairs of the Associated Advertising Clubs of the World, especially the "On to London" program of 1924. His campaign for honesty in advertising was in part responsible for his being one of the first ten men named to the Advertising Hall of Fame. ${ }^{26}$

Meredith's role as an innovator in publishing is well known, but public acceptance of his magazines still needs to be explored. There is considerable information in his papers about the origins and early growth of Better Homes and Gardens. Just what was there about this magazine, with its sharply-focused emphasis on service to the settled, middle-class American homeowner, that resulted in its spectaular

23 Arthur S. Link, "What Happened to the Progressive Movement in the 1920's?" American Historical Review, LXIV (July 1959), 833-851; Herbert F. Margulies, "Recent Opinion on the Decline of the Progressive Movement," MidAmerica, XLV (October 1963), 250-268.

24 For example, the letters of George Fort Milton and McAdoo to Meredith in late 1927 and early 1928 suggest that both men were far more active in opposing Al Smith than their papers at the Library of Congress indicate. In addition to Milton and McAdoo, Meredith corresponded with, among others, Bernard Baruch, Franklin D. Roosevelt, Cordell Hull, Newton Baker, Breckinridge Long, Daniel Roper, Hollins Randolph, Josephus Daniels, and David L. Rockwell.

25 William E. Leuchtenburg, The Perils of Prosperity 1914-32 (Chicago, 1958), p. 178.

26 Des Moines Register, June 4, 1949. 
growth? Perhaps one should look for the answer in the nature of American society in the decade.

FARM RELIEF. Much has been written about the efforts to promote recovery for agriculture during this period, but the subject has not been exhausted. Meredith, as a publisher of farm journals, was vitally interested in agricultural conditions. Yet his concern surpassed the simple matter of personal business, and he shared with many the conviction that a healthy rural America was fundamental to the wellbeing of the entire nation.

Seldom did the former Secretary of Agriculture miss an opportunity to express his views on the ills of agriculture. He traveled extensively in an effort to promote his farm relief plan. With every speech or letter, he invited and even welcomed criticism. Many individuals, especially business acquaintances of Meredith, accepted the invitation. The result was some rather heated exchanges over the merits of various proposals for farm relief. Anyone interested in the history of agriculture would do well to examine these letters.

A small portion of the collection deals with one of the state's most celebrated libel cases-Meredith's suit against Senator Smith W. Brookhart. The Senator charged that Meredith, while serving as Secretary of Agriculture, had taken part in efforts to depress farm prices. Meredith countered with a suit asking for an award of thirty cents in damages.

LAND DEVELOPMENT. The Meredith papers include a fairly complete set of the business records of the Idaho Farm Development Company and fragmentary information on its predecessor, the West End Twin Falls Irrigation Company. The latter was an ambitious program inaugurated in 1907 to irrigate 570,000 acres of arid land in southern Idaho. The company soon suffered financial reverses, and the project lay dormant until the chartering of its successor in 1919.

Edwin T. Meredith had financial interests in both companies, and he served as the treasurer of the Idaho Farm Development Company. The second project was far smaller than the original undertaking; yet it proved to be an expensive venture. By February 1924 Meredith estimated that he had spent $\$ 500,000$ on its development. Furthermore, he saw little chance of any substantial return on his investment. After Meredith's death, members of the family liquidated their holdings and the company folded. These papers therefore supplement previous studies of irrigation in Idaho. ${ }^{27}$

27 E.g., Mary Gunnell Lewis, "A History of Irrigation Development in Idaho," (Unpublished M.A. Thesis, University of Idaho, 1924), pp. 77-78. 
The possibilities for research in the Meredith papers suggested in this article are only some of the most obvious. Given the size of the collection, another observer could undoubtedly compile a comparable list of additional potential research topics. But the papers, and those responsible for their deposit in the Library, deserve better than long lists of possibilities; they deserve actual research. Edwin T. Meredith was an articulate participant in the American scene for most of his life. Imbued with a sense of social responsibility not often found in men of his financial and social status, he sought to shape American society. To ignore his efforts and his papers is to ignore a small yet important portion of the American past. 


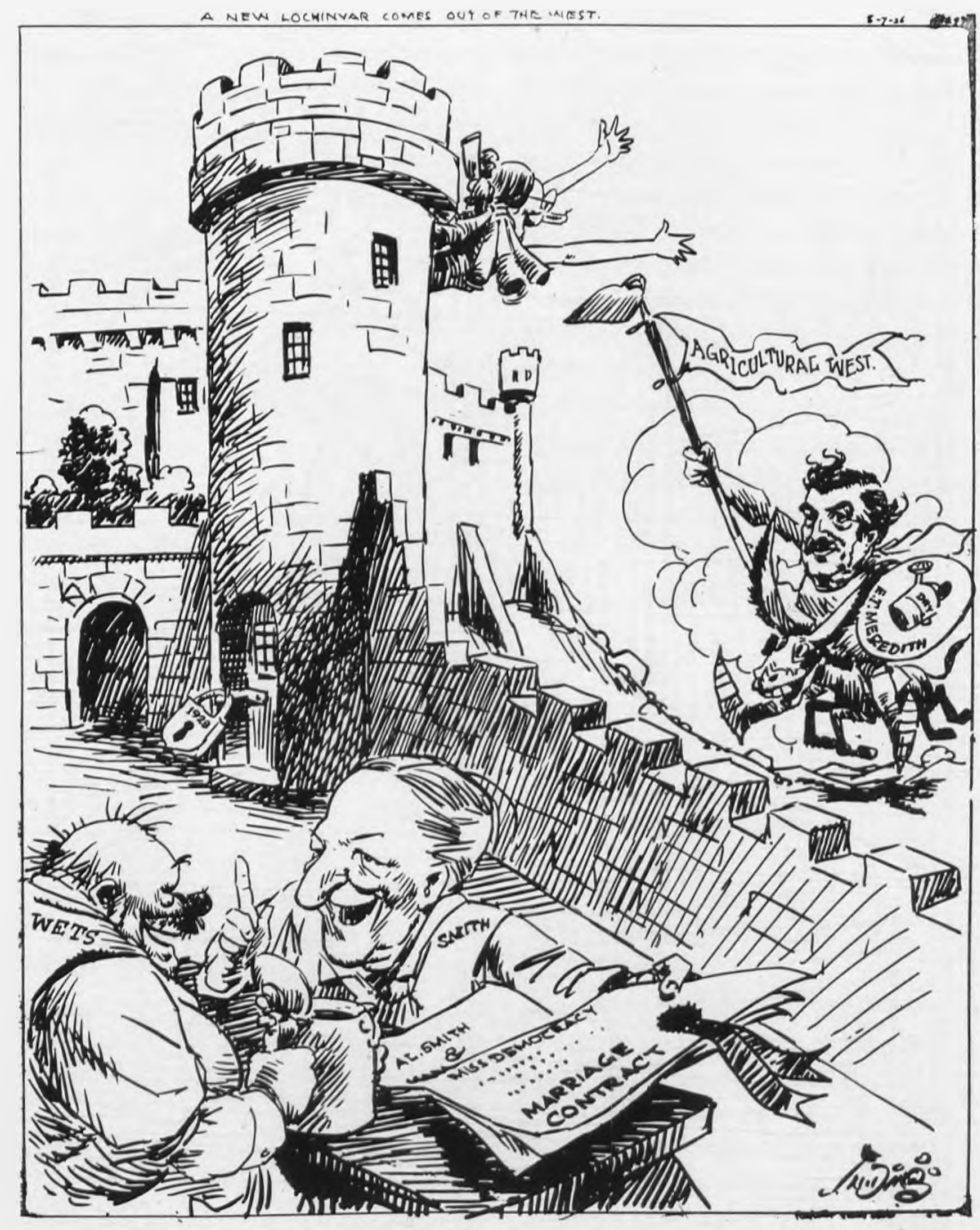

“A New Lochinvar Comes Out of the West," an editorial cartoon concerning E. 'J'. Meredith, drawn by "Ding" Darling for the Des Moines Register in August 1926. One of the six thousand original drawings preserved in the Library's "Ding" Darling Cartoon Collection. 